\title{
Margin Pemasaran dan Transmisi Harga Komoditi Jahe
}

\author{
Julia Hutauruk \\ Program Studi Agribisnis Universitas Katolik Santo Thomas Medan \\ Email : Julia_hutauruk@ust.ac.id
}

\begin{abstract}
Abstrak
Jahe merupakan komoditas tanaman obat yang banyak diminati saat ini baik oleh pasar dalam negeri maupun luar negeri. Tanaman jahe memiliki peluang potensial pada masa pandemi seperti saat ini karena jahe banyak dicari oleh masyarakat untuk dijadikan sebagai obat atau ramuan tradisional penambah daya tahan tubuh. Penelitian ini bertujuan untuk mengetahui besarnya biaya pemasaran, sebaran harga, dan bagian yang diterima masing-masing lembaga dan transmisi harga serta efisiensi pada saluran pemasaran jahe di daerah penelitian. Penentuan daerah penelitian dilakukan secara Puposive atau sengaja yaitu di desa Amborgang. Dalam penelitian ini, metode analisis yang digunakan dalam penelitian ini adalah metode deskriptif dan tabulasi sederhana untuk margin pemasaran. Berdasarkan hasil penelitian disimpulkan bahwa ada 2 saluran pemasaran jahe yang terdapat di daerah penelitian. Hasil penelitian menunjukkan bahwa saluran yang paling efisien adalah saluran pemasaran IIA. Elastisitas transmisi harga menunjukkan bahwa kedua saluran tersebut adalah inelastis.
\end{abstract}

Kata kunci : produk, margin, elastisitas, komoditi

\begin{abstract}
Ginger is a medicinal plant commodity that is currently in great demand by both domestic and foreign markets. Ginger plants have potential opportunities during a pandemic like today because ginger is sought after by the public to be used as medicine or traditional herbs to increase endurance. This research is aimed to know the amount of marketing costs, price distribution, and the share received by each institution and price transmission and efficiency in the marketing channel of ginger in the research area. The determination of the research area was carried out purposively or intentionally, namely in Ambogang Village. In this research, The analytical method used in this research is descriptive method and simple tabulation for marketing margins. Based on the results of the study, it was concluded that there were 2 marketing channels for ginger in the research area. The results showed that the most efficient channel was the IIA marketing channel. The price transmission elasticity indicates that the two channels are inelastic.
\end{abstract}

Keywords: product, margin, transmcyi elasticity

\section{PENDAHULUAN}

Tanaman rempah obat-obatan tidak hanya potensial dalam negeri saja, tetapi juga berpeluang besar diserap oleh konsumen dari berbagai dunia. Tanaman rempah dan obat-obatan juga berpotensi sebagai komoditas ekspor nonmigas. Salah satu tanaman rempah-rempah dan obat-obatan yang berpotensi besar untuk dikembangkan secara komersial dan berwawasan agribisnis adalah jahe (Rukmana, 2000).

Jahe merupakan komoditas tanaman obat yang banyak diminati saat ini baik oleh pasar dalam negeri maupun luar negeri. Komoditas ini menempati posisi yang sangat penting dalam perekonomian masyarakat indonesia karena jahe memiliki banyak manfaat. Salah satunya digunakan sebagai bahan mentah dalam pembuatan obat modern maupun obat tradisional (Paimin et al, 2004).

Tanaman jahe memiliki peluang potensial pada masa pandemi seperti saat ini karena jahe banyak dicari oleh masyarakat untuk dijadikan sebagai obat atau ramuan tradisional penambah daya tahan tubuh. Konsumsi jahe di masyarakat meningkat tajam, seiring dengan penyebaran virus
Corona atau Covid-19 yang semakin meluas. Meningkatnya konsumsi jahe di masyarakat mulai terlihat sejak kasus pertama virus Corona muncul di Indonesia.

Tujuan Penelitian ini adalah untuk untuk mengetahui besarnya biaya pemasaran, sebaran harga, dan bagian yang diterima masing-masing lembaga, dan mengetahui tingkat efisiensi tataniag pemasaran jahe serta untuk mengetahui elastisitas transmisi harga ditingkat petani dan pengecer .

\section{METODE PENELITIAN}

Penelitian ini dilakukan berdasarkan
penelusuran data dari $\quad$ Desa Amborgang Kecamatan Porsea Kabupaten Toba. Pemilihan lokasi dilakukan secara sengaja (purposive) dimana kecamatan ini merupakan daerah penghasil jahe yang memiliki sentra produksi jahe paling tinggi di Kabupaten Toba dan di desa Amborgang mayoritas penduduknya mengusahakan tanaman jahe. Dengan metoda snow ball sampling dilakukan penelusuran data mulai dari petani di desa Amborgang sampai tingkat konsumen di daerah lain 


\section{Metode Pengumpulan Data}

Data yang dikumpulkan pada penelitian ini terdiri dari data primer dan data sekunder. Data primer diperoleh melalui wawancara langsung dengan petani sampel dan pedagang (baik di wilayah pene;itiansampai di wilayah konsumen) dengan menggunakan kuesioner yang telah disusun sebelumnya. Data sekunder diperoleh dari Dinas maupun instansi yang terkait dengan tujuan penelitian yaitu:

\section{Metode Analisis Data}

Alat analisis yang digunakan adalah:

a. Tujuan penelitian pertama dan ketiga digunakan analisis deskriptif dengan menggunakan tabel.

b. Untuk identifikasi masalah yang kedua digunakan analisis deskriptif dengan bantuan rumus elastisitas transmisi harga:

*Sebaran Harga

$M_{\mathrm{ji}}=\mathrm{Psi}-\mathrm{Pbi}$

$\mathrm{Mj}=$ Margin pada lembaga persamaan kei

Psi = Hargajual pada lembaga pemasaran tingkat ke-i

Pbi = Harga beli lembaga pemasaran tingkat ke-i

Bti $=$ Biaya pemasaran tingkat ke-i

I $=$ Keuntungan persamaan tingkat ke-i

* Share Margin

$\mathrm{S}_{\mathrm{m}}=\frac{P p}{P k} \times 100 \%$

di mana:

$\mathrm{Sm}=$ Share margin dihitung dalam persen $(\%)$

$\mathrm{Pp}=$ Harga yang diterima produsen atau pedagang

$\mathrm{Pk}=$ Harga yang dibayar oleh konsumen akhir

*Efisiensi Pemasaran

$\mathrm{Ef}=\frac{\text { Biaya Pemasaran }}{\text { Nilai Produk yang dipasarkan }} \times 100 \%$

* Elastisitas transmisi harga

$\mathrm{Et}=\mathrm{dPyr} / \mathrm{dPf}: \mathrm{Pf} / \mathrm{Pr}$

$\mathrm{Et}=1 / 1-\mathrm{b} \cdot \mathrm{Pf} / \mathrm{Pr}$
Dimana

Et + Elastisitas transmisi Harga dPr perubahan harga di tingkat konsumen dPf perubahan harga di tingkat petani Pr harga di tingkat konsumen dan Pf harga di tingkat petani

Jika Et $<1$ kepekaan perubahan nisbi di tingkat petani lebih kecil dari pada ditingkatt konsumen dan jika Et > 1 maka kepekaan di tingkat petani lebih besar dari pada di tingkat konsumen

Jika Et $=1$ maka kepekaan nisbi di tingkatnpetani sama dengan kepekaan nisbi di tingkat konsumen

\section{HASIL DAN PEMBAHASAN \\ Pola dan Lembaga Pemasaran Jahe}

Saluran pemasaran merupakan jalur dari lembaga pemasaran yang dilalui dalam menyalurkan barang dari produsen ke konsumen. Berdasarkan hasil penelitian yang telah dilaksanakan dapat diuraikan mengenai pola dan lembaga saluran pemasaran jahe di Kecamatan Porsea Kabupaten Toba. Pengumpulan data untuk mengetahui berbagai hasil pemasaran jahe yang digunakan, diperoleh dengan cara penelusuran jalur pemasaran jahe mulai dari petani sampai pada konsumen. saluran pemasaran melibatkan beberapa lembaga pemasaran (pedagang pengumpul, pedagang besar, pedagang pengecer) yang menyalurkan jahe dari desa Amborgang Kecamatan Porsea untuk disampaikan kepada konsumen dalam negeri.

Dari hasil penelitian diperoleh bahwa ada dua saluran pemasaran di desa Amborgang adalah:

Saluran I : Petani -> Pedagang Besar -> Pedagang Pengecer -> Konsumen.

Perbedaan 1a 1b dan 1c adalah berdasarkan daerah tujuan konsumen yakni siantar Medan dan porsea Saluran II : Petani -> Pedagang Pengumpul Desa $>$ Pedagang Besar -> Pedagang Pengecer -> Konsumen.

Perbedaan $2 \mathrm{a}$ dan $2 \mathrm{~b}$ berdasarkan tujuan daerahn konsumen

\section{Margin Pemasaran}

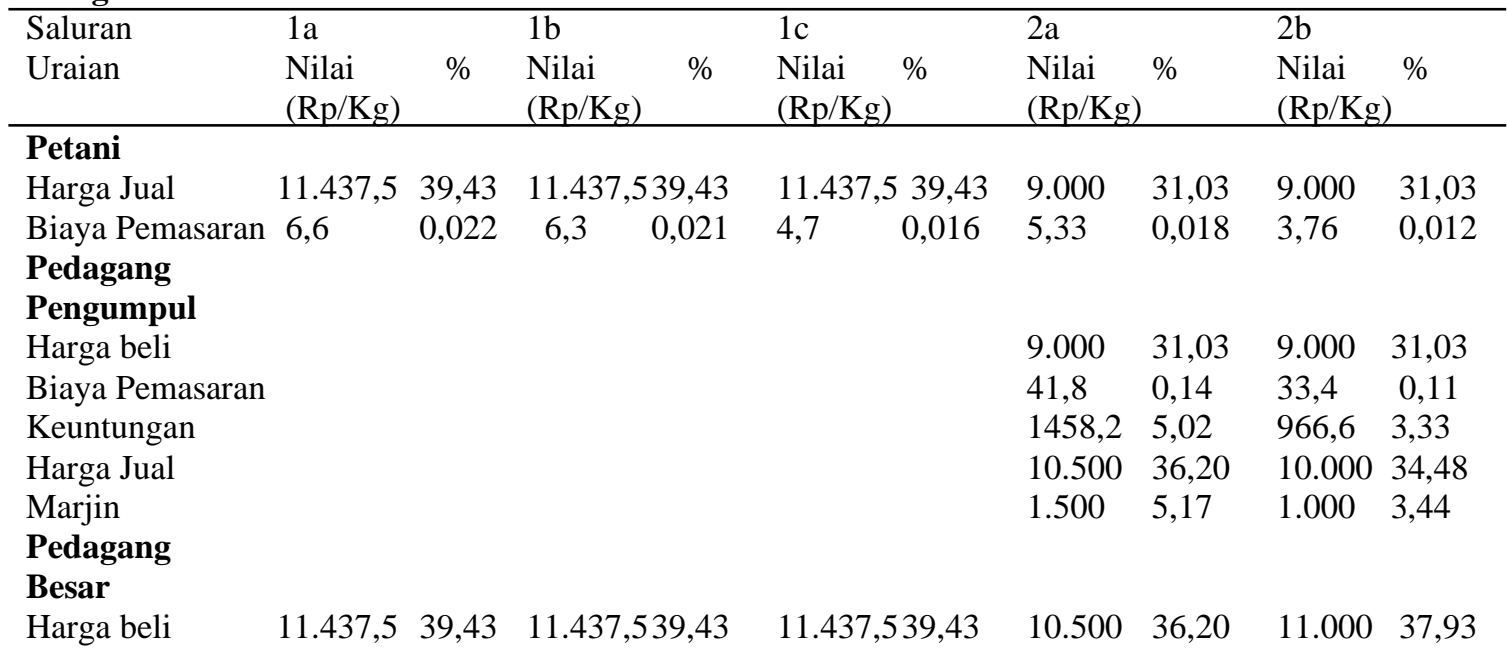




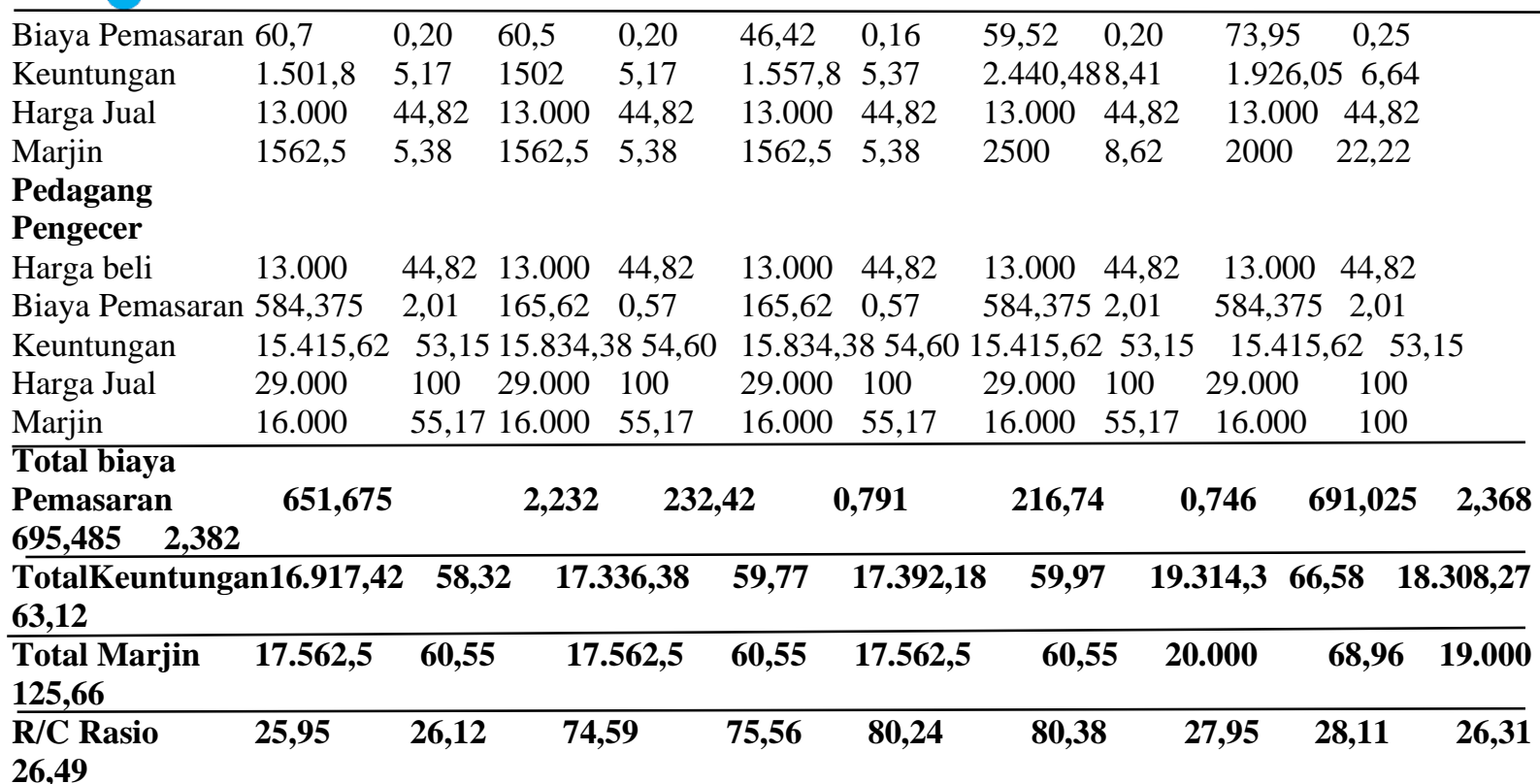

Berdasarkan hasil penelitian margin pemasaran bahwa margin biaya terkecil adalah pada saluran pemasaran I, akan tetapi lembaga pemasaran yang berperan hanya pedagang besar dan pedagang pengecer. Maka dipilih saluran pemasaran II yaitu biaya terkecil kedua yang lebih efisien.

\begin{tabular}{lccc} 
Saluran Pemasaran & $\begin{array}{l}\text { Harga di Tingkat } \\
\text { Petani }(\mathbf{R p} / \mathbf{K g})\end{array}$ & $\begin{array}{c}\text { Harga di Tingkat } \\
\text { Konsumen }\end{array}$ & $\begin{array}{c}\text { Farmer's } \\
\text { Share (\%) }\end{array}$ \\
\hline IA & $11.437,5$ & 29.000 & 39,43 \\
IIA & 9.000 & 29.000 & 31,03 \\
\hline
\end{tabular}

Berdasarkan farmer's share maka saluran pemasaran IA menunjukkan farmer's share terbesar akan tetapi jumlah yang diperjualbelikan lebih kecil dari lembaga pemasaran IIA. Maka dipilih saluran pemasaran IIA (farmer's share kedua terbesar) yang lebih efisien.

\begin{tabular}{|l|l|l|l|}
\hline Lembaga Pemasaran & Keuntungan $(\mathrm{Rp} / \mathrm{Kg})$ & Biaya $(\mathrm{Rp} / \mathrm{Kg})$ & $\pi / \mathrm{C}$ \\
\hline Saluran Ia & $28.348,32$ & 645.075 & 51.11 \\
\hline Saluran Ib & $28.767,58$ & 226,12 & 120.42 \\
\hline Saluran Ic & $28.824,98$ & 212.04 & 129,15 \\
\hline Saluran IIa & $28.308,97$ & 685.695 & 102.25 \\
\hline Saluran Iib & $27.304,51$ & 691.725 & 81.35 \\
\hline
\end{tabular}

Berdasarkan rasio keuntungan terhadap biaya maka saluran pemasaran IIA menunjukkan rasio terbesar. Sedangkan rasio keuntungan biaya terbesar diperoleh pada saluran pemasaran IC yaitu Rp.129,15. Akan tetapi yang dipilih adalah saluran pemasaran IIA yang lebih efisien yaitu sebesar Rp. 102,25. Pada saluran ini potensi pasar dalam menjual belikan jahe yaitu pedagang langsung menjemput jahe di lokasi dan meringankan petani dalam hal pengangkutan saat pemasaran tersebut.

Elastisitas Transmisi Harga dengan menggunakan rebresi perubahan harga di tingkat produsen dengan perubahan harga di tingkat konsumen diperroleh
Farmer's Share

Farmer's share merupakan perbandingan antara harga yang diterima petani dengan harga yang dibayarkan oleh konsumen, dan pada umumnya dinyatakan dalam bentuk persentase.

\section{Rasio Keuntungan dan Biaya}

Biaya pemasaran adalah biaya yang dikeluarkan oleh lembaga pemasaran dalam menyalurkan jahe dari petani ke konsumen akhir yang dinyatakan dalam bentuk rupiah per $\mathrm{kg}$. 


\section{Saluran II}

Nilai elastisitas transmisi harga (Et) pemasaran jahe dari desa Amborgang Kecamatan Porsea adalah 0,02. Elastisitas transmisi pemasaran tersebut bernilai kurang dari satu $(\mathrm{Et}<1)$. Hal ini diartikan bahwa setiap perubahan harga di tingkat pengecer sebesar $1 \%$ maka perubahan harga di tingkat produsen kurang dari $1 \%$ atau sebesar $0,02 \%$.

\section{KESIMPULAN}

Berdasarkan hasil penelitian dan pembahasan mengenai saluran pemasaran jahe di daerah penelitian, maka diperoleh kesimpulan sebagai berikut : (1) Terdapat 2 saluran pemasaran. (2) Berdasarkan hasil analisa margin, farmer's share dan rasio keuntungan menunjukkan bahwa semua saluran sudah efisien tetapi yang paling efisien adalah saluran pemasaran IIA. (3) Berdasarkan analisis elastisitas transmisi harga dari kedua saluran diperoleh elastisitas transmisi harga pada saluran I sebesar 0,21 ,elastisitas saluran II sebesar 0,02. Kedua saluran tersebut mempunyai elastisitas $<1$ atau inelastis. Yang mengindikasikan bahwa kepekaan perubahan harga di tingkat petani jauk lebih kecil dari pada di tingkat konsumen

\section{DAFTAR PUSTAKA}

Abidin,1991 Saluran Pemasaran Pertanian. Jasa Guna. Jakarta.

Azzaino, 1982. Manajemen Pemasaran, PT Raja Grafinda, Jakarta.

Daniel, 2002. Pengantar Ekonomi Pertanian. Cetakan Pertama. PT. Bumi Aksara, Jakarta.

Dinas Tanaman Pangan, 2020. Pemasaran Jahe pada masa pandemi. Semarang.

Hasrul,2019.Penanaman Jahe. Rajawali Press. Jakarta.

Paimin et al, 2004. Budidaya Jahe. Penerbit

Kanisius. Yogyakarta

Rukmana R, 2000. USAHA TANI JAHE

Dilengkapi dengan pengolahan jahe segar, Seri

Budi Daya. Penerbit Kanisius, Yogyakarta. 